\title{
Shareholder Wealth Effects of Dividend Policy Changes in an Emerging Stock Market: The Case of Cyprus*
}

\author{
Nickolaos Travlos \\ ALBA, Greece, and \\ Cardiff Business School, U.K. \\ Lenos Trigeorgis \\ University of Cyprus, Cyprus, and \\ University of Chicago, U.S.A. \\ Nikos Vafeas \\ University of Cyprus, Cyprus
}

This article examines the stock market reaction to announcements of cash dividend increases and bonus issues (stock dividends) in the emerging stock market of Cyprus. Both events elicit significantly positive abnormal returns, in line with evidence from developed stock markets. This study contends that special characteristics of the Cyprus stock market delimit applicability of most traditional explanations for cash and stock dividends in favor of an informationsignaling explanation. The empirical results are generally inconsistent with these contentions (JEL G34).

Keywords: cash dividends, emerging markets, stock dividends

\section{Introduction}

The value-relevance of dividend policy has been in the forefront of financial research since Miller and Modigliani's (1961) pioneering

\footnotetext{
*We have benefitted from the helpful comments of participants at the 1999 Financial Management Association International Conference, held in Barcelona, Spain. The research assistance of Tasoulla Spyrou, Pantelis Nikolaides, and Philio Demetriou is gratefully acknowledged. This project was partly funded by a European Community MED-CAMPUS program research grant.
}

(Multinational Finance Journal, 2001, vol. 5, no.2, pp. 87-112)

CMultinational Finance Society, a nonprofit corporation. All rights reserved.

DOI: $10.17578 / 5-2-1$ 
work. Prior empirical research, generally focused on firms listed in developed stock markets, suggests that the announcement of dividend increases, either in cash or stock, is associated with significantly positive stock market excess returns. In the case of cash dividends, this evidence is attributed to information-signaling and agency cost effects; in the case of stock dividends it is attributed to information-signalling and "optimal" trading price-range effects. While the focal point in studies performed in developed markets has shifted to explaining the positive wealth effects of dividend increases, the wealth impact of dividend policy changes in emerging markets is currently not well established. Given alternative market microstructure and different information, tax and control environments, the impact of dividend changes is likely to vary across economic environments in different countries.

The purpose of this study is to evaluate the role of cash and stock dividends (bonuses) in an emerging stock market. The Cyprus stock market is an interesting choice of an emerging market in assessing dividend policy changes because it differs from developed markets in several notable dimensions: First, firms listed in this market have, for the most part, highly concentrated ownership structures that may render a standard free-cash-flow explanation for dividend policy changes less likely. Second, over the period under study the Cyprus stock market generally lacked transparency, potentially allowing for exploitation of smaller shareholders by larger ones; such exploitation may be mitigated by dividend increases. Finally, the lack of fixed transaction costs and round-lot restrictions in trading in this market suggests that there is limited use for an optimal trading range for share prices. In this regard, empirical evidence on the value-relevance of dividend increases in this market provides a useful venue for revisiting alternative traditional explanations for dividend policy.

The test results reveal significantly positive stock market returns for firms announcing increases in cash and in stock dividends in line with our expectations. Additional tests, however, are unable to provide convincing evidence about the validity of alternative explanations for dividend policy. These results may be driven by methodological considerations such as imperfect empirical constructs and small sample sizes, or naïve investors that are unable to distinguish between information, agency, and liquidity considerations in a small emerging market. The remainder of the paper is organized as follows: Section II provides background on the Cyprus Stock Exchange, section III 
discusses the relevant literature and hypotheses, section IV describes the data and methodology, and section $\mathrm{V}$ presents and discusses the results. The last section concludes.

\section{The Cyprus Stock Exchange}

\section{A. Market Microstructure}

During the period under study (1985-1995), transactions in the Cyprus stock market took place primarily through a decentralized network of dealers/brokers in an over-the-counter market. The absence of a formal stock exchange was compensated in part through sponsorship and monitoring of this over-the-counter market by the Cyprus Chamber of Commerce and Industry (CCCI or KEVE). CCCI has been publishing daily quotations for bid and ask prices supplied by individual brokers, which were binding only for a specified minimum block of shares. Regular, centralized, auction-type meetings have been taking place at CCCI's premises where all the brokers convened to arrive at a single market price for traded securities. (There are no specialists or official market makers.) Typically these market prices set at each centralized meeting served as benchmarks for market price levels until the next such meeting. However, the absence of a continuous, high-volume auction market and of a regulated competitive environment left open the possibility that quoted prices might deviate from the underlying fundamental value for many securities.

Over this period the Cyprus Stock Exchange experienced several significant structural changes. First, there has been a substantial increase in the number of auction-type meetings at CCCI's premises that constituted a market trading "floor". This increase in the frequency of centralized, auction-type meetings was a definite sign of market progress. The prices arrived at the closing of each meeting were a much better indication of the underlying supply and demand than the price quotes published by a number of brokerage firms in the press before December 1990 when the number of meetings was small.

\section{B. Number of brokers and public firms}

Parallel to the increase in the frequency of auction-type meetings, the number of brokerage firms also increased substantially. By 1994 there were 12 approved brokerage firms (with two more firms serving 
their trial period), up from only five brokerage firms in 1985. The number of public companies also increased significantly, especially between 1985-1991, with the total number of public companies reaching 39 in 1994 (up from 13 in 1985). Thus a more active market for securities was developing in the early 1990's. A large increase in the daily price variance was observed in the early 1990's as compared to the late $1980^{\prime} \mathrm{s}$, consistent with a substantial improvement in market efficiency.

\section{The Legal Framework}

A law to provide for the development of the securities market in the Republic of Cyprus, the establishment and operation of a Cyprus Stock Exchange, the operation of a stock exchange Council and other related matters was voted by parliament in 1995 . After its formation, the Cyprus Stock Exchange council proceeded to formulate and propose a comprehensive set of regulations to govern the operation of the formal Cyprus Stock Exchange, which became effective in March 1996. The drafting and passage of an appropriate legal/institutional framework (e.g., governing information disclosure, new securities registration, credential requirements for brokers, etc.) was deemed crucial for the proper functioning and development of the capital market in Cyprus and the efficient allocation of economic resources.

\section{Literature Review and Hypothesis Development}

\section{A. Cash Dividends}

A significant stream of prior research in the United States has empirically documented that unexpected increases (decreases) in regular cash dividends generally elicit a significantly positive (negative) stock market reaction (see, for example, Fama et al. [1969] and Petit [1972]). Moreover, this finding persists even after controlling for contemporaneous earnings announcements (Aharony and Swary [1980]). In the same vein, Asquith and Mullins (1983) find that, like dividend increases, dividend initiations have a significant positive impact on shareholder wealth.

Much subsequent research has focused on explaining the dividendincrease induced positive stock market reaction. The predominant explanation, by far, has been the information-signaling hypothesis. 
Since managers have information that outside investors do not have, dividend policy is a costly-to-replicate vehicle for conveying positive private information to market participants. In line with these arguments, signaling models by Bhattacharya (1979) and Miller and Rock (1985), among others, find that dividend increases convey information about the firm's current and future cash flows. In addition to supportive eventstudy results, empirical studies by Ofer and Siegel (1987) and Healy and Palepu (1988) examine changes in dividend policy in relation to future earnings and related analysts forecasts, also consistent with the information-signaling hypothesis. Bernartzi, Michaely, and Thaler (1997) find that earnings are less likely to drop after a dividend increase; however, they do not find that dividend increases are followed by unexpected earnings increases. Their evidence is only weakly consistent with an information-signaling hypothesis. DeAngelo, DeAngelo and Skinner (1992) find that a loss is a necessary but not a sufficient condition for a dividend cut, and that dividend cuts improve the ability of current earnings to predict future earnings. Moreover, DeAngelo, DeAngelo, and Skinner (1992), Bernartzi, Michaely, and Thaler (1997), and Jensen and Johnson (1995) document that dividend cuts are followed by earnings increases, consistent with dividend cuts marking the end of a firm's financial decline and the beginning of its restructuring. In sum, the empirical evidence by prior research on the signaling value of dividend changes has been mixed.

An alternative explanation for changes in corporate dividend policy stems from agency theory. Jensen (1986) suggests that managers, motivated by compensation and human capital considerations, have incentives to over invest free cash flows even in the absence of profitable growth opportunities (the free cash flow hypothesis). Dividend payout policy in this case becomes a vehicle for monitoring the managers' potential to misuse excess funds. Thus, the observed positive stock market reaction following dividend increases is consistent, in addition to information-signaling, with a reduction in agency costs.

Lang and Litzenberger (1989) attempt to disentangle between signaling and agency explanations by separating firms that are presumably over investing (with $q$ ratios less than one) from all other value-maximizing firms. They find higher abnormal returns for over investing firms for which the agency-related benefits of a dividend payout increase are higher compared to value-maximizing firms. Consistent with the free cash flow hypothesis, the market reaction to 
dividend increases by value-maximizing firms, albeit positive, is significantly lower than the market reaction for over investors. By contrast, Denis, Denis, and Sarin (1994), after controlling for dividend yield, find no support for the free cash flow hypothesis for a large sample of dividend changes. Furthermore, Yoon and Starks (1995) do not detect the release of new information about managers' investment policies following a change in dividend policy. They find a positive relation between dividend policy changes and capital expenditure changes, interpreting their evidence as being supportive of an information-signaling over a free cash flow explanation of dividend policy. Also consistent with the free cash flow hypothesis, DeAngelo and DeAngelo (2000) find evidence that the market penalized Times Mirror for intending to poorly reinvest free cash flow and applauded later dividend redistributions of that cash flow. Finally, in a major international study, La Porta et al. (2000) find that dividends are paid because minority shareholders pressure corporate insiders to disgorge cash. Additional studies on the relevance of the free cash flow hypothesis for alternative payout methods such as share repurchases and special dividends have provided mixed results (e.g., Howe, He, and Kao [1992], Vafeas [1997], and Nohel and Tarhan [1998]). Despite mixed overall evidence on the free cash flow hypothesis, most researchers attribute the conflicting results to imperfect empirical constructs rather than theoretical flaws.

A third explanation is the tax hypothesis. Given the differential tax treatment between dividend income and capital gains, dividend policy changes also have tax implications that are reflected in stock market prices. In the United States, capital gains have historically been taxed more favorably than dividends. In Cyprus capital gains on stock investments have not been taxed at all while dividends received (beyond an exempt amount) are taxed at an individual's personal income tax rate. Therefore, capital gains would be preferable to most individual investors and dividend increases should elicit a negative stock price reaction. ${ }^{1}$ The observed positive stock market reaction of dividend increases for U.S. firms appears to be inconsistent with the unfavorable tax treatment of dividend income. Conceivably, any negative tax effect may be dominated by stronger positive signaling and/or free cash flow

1. Dividends are preferred only by some investors given differential marginal tax rates across investors. Prior literature has also posited a dividend clientele hypothesis according to which there is a natural clientele of investors that prefer stocks yielding higher dividends because of income-smoothing or tax considerations. 
effects. $^{2}$

Examination of the market reaction to dividend changes in an emerging market such as Cyprus can be a fruitful empirical exercise in that the relative import of alternative explanations of dividend policy may likely differ compared to a developed market. First, a clear implication of the standard free cash flow hypothesis as advanced by Jensen (1986) is the separation of ownership and control since wider ownership dispersion intensifies the conflict of interests between managers and shareholders. This conflict of interests generally motivates higher dividend payouts to limit the managerial tendency to misuse shareholder funds. In Cyprus firms are, for the most part, closely held, with ownership concentrated in the form of large equity blocks in the hands of management and family members. This may suggest that managers in Cyprus have a disincentive to misuse funds through over investing since the relative benefit of managing a larger firm is likely to be outweighed by the direct cost of over investing on the managers' substantial personal holdings in the firm. The point is, as ownership becomes more concentrated, the likelihood of over investment is reduced. Further, firm sizes are quite small in Cyprus so that the managerial "hubris" effect of inflating firm size is likely negligible.

However, in many of these family businesses there may be conflict of interests between the larger and the smaller shareholders. The problem may be more pronounced in many emerging markets when lack of transparency, both at the company level and in the stock market, allows alternative forms of exploitation of the smaller shareholders by the larger shareholders and management (see Holderness and Sheehan [1988]). Since monitoring is difficult in such cases, it may be substituted by higher dividends that may serve to mitigate this form of exploitation. Thus, although over investing free cash flow in the Cyprus market is likely to be limited due to concentrated corporate ownership structures, other forms of exploitation of smaller shareholders by larger shareholders and management may partly justify dividend increases, in addition to information signaling reasons. That is, small stockholders purchasing equity against large block holders expect to suffer a certain degree of exploitation. An unexpected increase in cash dividends

2. In line with the dominance of a signalling explanation over a tax explanation for the market reaction to dividend policy changes, Bernheim and Wantz (1995) document a positive relation between increases in the tax rate on dividends and the share price response per dollar of dividends. 
reduces the market's assessment of future exploitation by large block holders, causing an upward revision in the stock price.

The preceding discussion makes mixed predictions about the impact of cash dividends in the Cyprus stock market. The hypothesis to be tested, in its alternate form, is

$H_{1}$ : There is a positive and significant abnormal return following the announcement of an increase in cash dividends. ${ }^{3}$

\section{B. Stock Dividends (Bonus Issues)}

Stock dividends (referred to as bonus issues in Cyprus) effectively award existing shareholders a free share of common stock for every $\mathrm{X}$ shares currently owned. Strictly speaking, bonus issues constitute finer slicing of a given firm value and should have no direct wealth effects to shareholders if they have no cash flow implications. Yet, much academic research in the United States documents positive stock price responses to stock dividend (and stock split) announcements (e.g., Grinblatt, Masulis, and Titman [1984]). Moreover, Asquith, Healy and Palepu (1989) document abnormally positive earnings performance in the pre-split years. Last, McNichols and Dravid (1990) find a positive relationship between the stock dividend factor and the announcementrelated abnormal return.

Two predominant explanations for stock dividends are based on the information-signaling hypothesis and the "optimal" trading price-range hypothesis. Both hypotheses predict a positive impact of stock dividends on firm value and can explain why a firm may undertake such transactions given non-zero transaction costs. First, given information asymmetry between managers and investors, stock dividends are costly signals that convey management's positive private information about the firm's future prospects. Specifically in Cyprus, as in the U.S., companies must maintain a minimum level of retained earnings. Therefore, companies would transfer Retained Earnings to Common stock (and issue free shares) only if they expect future earnings to increase and, thus, future retained earnings to replace capitalized retained earnings. Investors, therefore, may interpret the stock dividend as good news. McNichols and Dravid (1990) provide evidence that is consistent with a signaling explanation for stock dividends.

3. An analogous examination of the wealth impact of dividend cuts was not feasible due to the rare occurrence of such events. 
Second, it is argued that high trading prices are inaccessible to small investors who may be unable to buy shares in round lots. Therefore, to achieve higher liquidity, many firms aim at lower trading prices. Conversely, larger institutional investors prefer trading shares at higher prices because of the fixed transaction cost component. Together, these influences suggest the existence of an optimal trading price range for firms to improve marketability of their stock. Stock dividends, like stock splits, can therefore be a tool towards attaining such an optimal trading price for firm shares. Lakonishok and Lev (1987), among others, provide empirical evidence that is consistent with firms employing stock dividends and stock splits in order to shift share prices to an optimal trading level. In line with this notion, Kryzanowski and Zhang (1996) document significant changes in trading patterns following stock splits, including fewer odd-lot trades and increases in small (trade value of less than $\$ 10,000$ ) board-lot trading. In a related vein, Angel (1997) finds that market microstructure considerations determine when a stock split is appropriate, such as an optimal ratio of tick size to stock price. Thus, minimum price variation rules may help explain why stock prices vary substantially across countries. Similarly, Angel, Brooks, and Mathew (1998) find evidence that the higher volatility that has been documented following stock splits is a function of the different share price regime and not due to the release of new information revealed on the ex-date about the stock's volatility. By contrast, others (e.g., Copeland [1979]) have reported lack of supporting evidence regarding liquidity gains around stock splits. Further, Schultz (1999) suggests that after the split trading costs increase and market making costs decline, suggesting that the increase in the number of small shareholders after the split may be the result of brokers having more incentives to promote these stocks more actively. In sum, as in the case of cash dividends, it is very difficult, if not impossible, to control for one explanation of stock dividend activity while testing another explanation in isolation; thus, empirical studies on the topic may be consistent with one, but can not conclusively eliminate the other hypothesis.

The case of stock dividends in the Cyprus market is appealing in that it provides a setting that delimits the importance of the optimal trading price-range hypothesis as an explanation for stock dividends. Therefore, the stock market reaction to stock dividends observed in our sample firms is more likely to stem from information-signaling effects. First, small investors in the Cyprus stock market should be indifferent 
to the trading price of shares because current rules impose no round-lot requirements in making trades. Investors are free to trade almost any number of shares without bearing volume-related costs. Moreover, none of the over-a-dozen official brokerage houses operating in the Cyprus stock market were charging a fixed fee in executing trades on behalf of investors. Trading costs are therefore variable with the size of the order, being a function of the total value of the shares being traded. This fact diminishes preference for higher trading prices that is exhibited by large institutional investors in the United States. Taken together, these market characteristics suggest that, in this emerging stock market, investors should be relatively less sensitive to "optimal" trading ranges for stock prices. As a result, stock dividends in Cyprus are less likely to aim at adjusting share prices to more desirable levels. Therefore, information-signaling (and, indirectly, exploitation by larger shareholders or tax) effects may be more plausible explanations for stock dividend activity in Cyprus. The hypothesis to be tested is

$\mathrm{H}_{2}$ : There is a positive and significant abnormal return at the announcement of a stock dividend (bonus issue).

\section{Data and Methodology}

Event announcement dates for both cash and stock dividends (bonus issues) were collected after direct contact with the Managing Board of the Cyprus Stock Exchange which managed the stock market unofficially during the eleven-year sample period 1985-1995 when daily stock returns were available. Firms that were listed in the stock exchange during this period had to officially inform the Managing Board of their dividend payouts (both in cash and in stock). The date of that communication constituted the event date. In general, that date coincided with a board of directors' meeting since the decision presupposed approval by the board.

Cash dividend payouts are usually announced semi-annually by the larger public firms and annually by the smaller firms in the Cyprus Stock Exchange (no quarterly dividend announcements were observed during the sample period). Other types of announcements coinciding with and confounding dividend announcements were very rare during the sample period. For example, over the entire eleven-year period under study there was only one takeover of a public firm, no stock 
splits, and no share repurchases (these were illegal over this sample period). Infrequently, dividend announcements were accompanied by coincident earnings announcements. However, no separate record of these announcements was kept and given the fairly limited number of usable observations in our analysis we have opted not to discard any observations on the basis of other contemporaneous news releases. In any case, the statistical significance of the market reaction to the events under consideration is similar using both the parametric and nonparametric tests, providing reasonable assurance that the documented market reactions are not the result of a few outliers that are potentially confounded by coincident earnings announcements.

A total of 181 cash dividend announcements by 31 different firms took place during the period under study. Of these, 41 announcements of cash dividends represented an increase over prior period cash dividends and comprise the cash dividends sample employed in this study. Further, 39 announcements of stock dividends by 30 different firms took place in the sample period and comprise the stock dividends sample. The most cash dividend increase announcements occurred in 1994 (eight) and the least in 1985 (none). Cash dividend increases are otherwise distributed fairly evenly across sample years, ranging from two to five. A relatively high number of dividend increases occurring in 1994 (8) and in 1995 (4) might be explained by the fact that exploitation of smaller shareholders by large ones is expected to decline given stricter government controls after the establishment of a formal CSE on March 1, 1996. Stock dividend announcements appear to occur randomly through time, exhibiting no discernible pattern of occurrence. Stock dividend announcements ranged from one in 1986 and 1994 to nine in 1992. Finally, there appears to be no correlation in the occurrence of the two types of dividends in each year.

It should be noted that all firms in the Cyprus Stock Exchange have highly concentrated ownership structures. As discussed earlier, the vast majority of firms listed in the Cyprus Stock Exchange over the sample period are included in our samples of cash dividends and stock dividends (30 and 32 firms, respectively, out of 38 firms total). Therefore, our sample firms' ownership structure is proxied well by the wider ownership characteristics of the population. CSE regulations mandate that a single ownership interest may not own more than $70 \%$ of the voting class of securities of any public firm. Further, the four largest shareholders collectively may not own more than $75 \%$ of the shares, ensuring that at least $25 \%$ of the voting stock is dispersed among 
the public. Importantly, in all firms that are traded in the CSE the four largest investors own at least $50 \%$ or more of the outstanding stock; that percentage routinely fluctuates between $65 \%$ and $75 \%$. This suggests very little cross-sectional variation in ownership concentration in the CSE. Unfortunately, such uniformity forbids us from performing any meaningful statistical tests using differences in ownership structure to differentiate between alternative explanations for dividend changes across firms.

For the completion of this study we used an electronic database with daily stock returns of all firms traded in the Cyprus stock market during the period 1985-1995 developed by one of the authors and his associates. Given the lack of liquidity for the period examined, in certain days no trading took place for some of the stocks. In such cases we assumed that the closing price was the mid-point between the bid and ask prices for that day. The shareholder wealth effect for the dividend announcements was determined using standard event-study methodology based on the single-factor market model (using riskadjusted returns), as well as the market-adjusted model (assuming a beta of 1 for all firms).

Specifically, the assessment of announcement-related abnormal returns follows standard event-study methods (e.g., Dennis and McConnell, [1986]) and was carried out as follows. First, each firm's returns were assumed to follow the single-factor market model,

$$
R_{j, t}=a_{j}+b_{j} R_{m, t}+e_{j, t},
$$

where $R_{j, t}$ is the rate of return of the common stock for the $j^{\text {th }}$ firm on day $t, R_{m, t}$ is the rate of return for the (equally-weighted) market index $(m)$ on day $t$, and $e_{j, t}$ is a random variable that is expected to have a value of zero. The abnormal return $(A R)$ for the $j^{\text {th }}$ common stock on day $t$ is given by

$$
A R_{j, t}=R_{j, t}-\left(a_{j}+b_{j} R_{m, t}\right),
$$

where the coefficients $a$ and $b$ are Ordinary Least Squares estimates of $a_{j}$ and $b_{j}$, estimated from a regression of daily security returns on daily market returns from $t=-200$ to $t=-51$ (where $t=0$ is the event date).

In thin markets such as the Cyprus Stock Exchange, autocorrelation in daily returns may lead to shifts in the betas. To address this concern, the betas for all firms that were traded in the CSE were re-estimated to account for beta shifts in time. Autocorrelation-adjusted betas were 
estimated using daily, weekly, and monthly returns over this period. Two adjustment techniques were used: The Scholes and Williams (1988) technique, where one lead and one lag beta factor are added to the standard market model, and the Dimson (1988) technique where three lagged or three lead beta factors are added to the standard market model. With a few negligible exceptions, these checks suggest that the betas under these two methods are not substantially different from the betas provided by a standard OLS market model regression, suggesting that autocorrelation does not meaningfully affect our results. Beta comparisons under the three methods are available from the authors upon request. ${ }^{4}$

Another method we used to estimate abnormal returns to further check the sensitivity of our results was simply to subtract the market return (using the equally-weighted market index), $R_{m, t}$, from the corresponding firm return over a given period $t .^{5}$ That is,

$$
A R_{j, t}=R_{j, t}-R_{m, t}
$$

This approach makes the assumption that the beta for all firms is 1 (and $a_{j}=0$ ), thus providing an extreme test of the sensitivity of the results to beta estimation or shifts.

Cross-sectional average daily risk-adjusted and market-adjusted returns are then computed for each class of securities as

$$
\overline{A R}_{i}=\sum_{j=1}^{N} \frac{A R_{j, 2}}{N}
$$

where $N$ is the number of events in the sample. Additionally, crosssectional average risk-adjusted returns are summed to yield a cumulative risk-adjusted return for event day $t$ as

4. For dividend announcements from 1985, it was necessary to estimate the market model from $t=+51$ to $t=+200$ after the event date. All tests in this paper were repeated after estimating the market model parameters over the period from $t=-240$ to $t=-121$.

5. In addition to serial independence of returns, an assumption made by standard event study methods is that the event itself does not induce significant variance in the returns. Boehmer et al. (1991) find that event-induced variance may lead to rejection of the null hypothesis of zero average returns too frequently. We do not account for this in our analysis. 


$$
C A R_{t}=\sum_{t-T}^{t} \overline{A R}_{k}
$$

where $T$ is a specified number of event days prior to the event day $t$.

To test the null hypothesis that the average daily risk-adjusted return on event day $t$ is equal to zero, we computed the $t$-statistic

$$
t=\frac{\overline{A R}_{t}}{\left(\sigma_{t} \sqrt{N}\right)}
$$

where

$$
\sigma_{t}=\left[\sum_{j=1}^{N} A R_{t, j}^{2}-\frac{1}{N}\left(\sum_{j=1}^{N} A R_{i, j}\right)^{2}\right]^{1 / 2}
$$

is the cross-sectional standard deviation of risk-adjusted returns on event day $t$. Under the null hypothesis of no abnormal security performance, $t$ is distributed according to the $t$-distribution with $N-1$ degrees of freedom.

To test the null hypothesis that the $C A R$ over an interval of $I$ days is equal to zero, a $t$-statistic is computed as:

$$
t_{I}=\frac{C A R_{I}}{\sigma_{I} \sqrt{I}}
$$

where

$$
\sigma_{1}=\left[\left(\sum_{i=1}^{i}\left(\overline{A R}_{k}-\frac{C A R_{j}}{I}\right)^{2}\right) / I\right]^{1 / 2},
$$

where $I$ is the interval length prior to event day $t$ and $C A R_{I}$ is the cumulative risk-adjusted and market-adjusted return over the $I$ - day interval beginning with event day $t-I$ and ending with event day $t$. Under the null hypothesis of no abnormal performance $t_{I}$ is distributed unit normal with $I$ degrees of freedom.

It is important to emphasize that our market-adjusted results abstract from beta estimation or beta shift issues. As it turns out, these results are very similar to the results using the market model adjustments. 
Therefore, the estimation and stability of the betas is unlikely to be a major determinant of the results that are reported in this paper.

\section{A. Presentation and Discussion of Results}

Table 1, panel A presents daily abnormal returns $(A R)$ for days -4 to +4 , and panel $\mathrm{B}$ shows the cumulative abnormal return $(C A R)$ results for the samples of 41 cash dividend increases and 39 stock dividend (bonus) announcements over alternative event-period windows. Focusing on the market model (or risk-adjusted) daily returns on the left-hand column of panel A, we observe that six of the nine returns are positive and days -3 and 0 are statistically significant. Market-adjusted results (on the right-hand column) for cash dividend increases are very similar. Moving to cumulative abnormal returns in panel $\mathrm{B}$, a conventional twoday window $(-1,0)$ reveals a marginally insignificant positive wealth effect surrounding the cash dividend increase announcements (marginally significant using market-adjusted returns). When the event window is widened to include additional trading days $(-2$ to +2$)$ before and after the announcement, the cumulative abnormal returns are positive and statistically significant $(1.886 \%$ with a $t$-statistic of 2.14 for risk-adjusted and $1.453 \%$ with a $t$-statistic of 2.60 for marketadjusted returns). Interestingly, abnormal returns are statistically insignificant in the eleven trading days prior to the event $(-15,-5)$ and eleven trading days after the event $(+5,+15)$ signifying that there is no information leakage or delay in market reaction to cash dividend announcements.

Overall, the results in table 1 are supportive of hypothesis $H_{1}$. The positive stock market reaction to cash dividend increases is at odds with a tax-motivated shareholder preference for (non-taxable) capital gains over dividend income, but is consistent with an information-signalling role for cash dividend increases. Although a standard free-cash-flow/ over investment explanation is less likely to directly apply in the Cyprus setting due to concentrated ownership structures, the positive reaction is also consistent with a reduction in potential exploitation of smaller shareholders by larger ones.

Turning to the market response to stock dividend (bonus) announcements presented in the right-most columns in table 1, panel A shows significant positive daily abnormal returns on five days surrounding the announcement, both under the risk-and market-adjusted benchmarks for estimating the abnormal returns. In fact, with the 
TABLE 1. The Stock Market Reaction to Dividend Changes in the Cyprus Stock Exchange

\begin{tabular}{|c|c|}
\hline Market Model ( risk-adjusted) & Market-Adjusted $(\beta=1)$ \\
\hline Cash Dividends Stock Dividends & Cash Dividends Stock Dividends \\
\hline
\end{tabular}

A. Daily Abnormal Returns $(A R)$

$\begin{array}{lcccc}\begin{array}{l}\text { Day } \\ -4\end{array} & -.093 & .362^{* *} & -.113 & .352^{* *} \\ & (-.56) & (2.01) & (-.64) & (2) \\ -3 & .466^{* * *} & -.594 & .386^{* *} & -.497 \\ & (2.6) & (-.82) & (2.17) & (-.7) \\ -2 & .112 & .27^{*} & .08 & .28^{*} \\ & (.43) & (1.67) & (.33) & (1.9) \\ -1 & -.274 & .345^{* *} & -.162 & .368^{* * *} \\ & (-1.34) & (2.22) & (-1.04) & (2.67) \\ 0 & .798^{* *} & .513 & .802^{*} & .614 \\ & (2.09) & (1.3) & (1.94) & (1.5) \\ +1 & .517 & 1.643^{* * *} & .376 & 1.623^{* * *} \\ & 1.43 & (3.68) & (1.27) & (3.75) \\ +2 & .141 & .467^{* *} & .219 & .416^{* *} \\ & (.78) & (2.33) & (1.26) & (2.14) \\ +3 & -.099 & .271 & -.034 & .299^{*} \\ & (-.49) & (1.6) & (-.2) & (1.9) \\ +4 & .628 & .211 & .188 & .208 \\ & (1.19) & (1.18) & (.86) & (1.18)\end{array}$

B. Cumulative Abnormal Returns $(C A R)$

\begin{tabular}{lcccc} 
Period & & & & \\
$(-15,-5)$ & 1.085 & .82 & .406 & $1.028^{*}$ \\
& $(.92)$ & $(1.58)$ & $.42)$ & $(1.94)$ \\
$(-1,0)$ & .654 & $.789^{* *}$ & $.595^{*}$ & $.899^{* *}$ \\
& $(1.6)$ & $(1.97)$ & $(1.66)$ & $(2.19)$ \\
$(-2,+2)$ & $1.886^{* *}$ & $3.141^{* * *}$ & $1.453^{* * *}$ & $3.187^{* * *}$ \\
& $(2.14)$ & $(4.63)$ & $(2.60)$ & $(4.89)$ \\
$(-4,+4)$ & .594 & $3.397^{* * *}$ & .527 & $3.552^{* * *}$ \\
& $(.59)$ & $(3.31)$ & $.64)$ & $(3.63)$ \\
$(+5,+15)$ & 1.851 & .473 & 1.161 & 0.781 \\
& $(1.24)$ & $(0.62)$ & $(.99)$ & $(0.96)$ \\
$(-15,+15)$ & 3.531 & $4.603^{* * *}$ & 2.094 & $5.271^{* * *}$ \\
& $(1.17)$ & $(3.07)$ & $(.97)$ & $(3.24)$ \\
\hline
\end{tabular}

Note: Announcement-induced daily abnormal returns (panel A) and selected cumulative abnormal returns (panel B) for cash dividend increases $(n=41)$ and stock dividends $(n=39)$ using market model (risk-adjusted) and market-adjusted $(\beta=1)$ benchmarks. $t$-statistics are in parentheses. ${ }^{* * *},{ }^{* * *}$, significant at the $.10, .05$, and .01 level, respectively. 
exception of day -3 , average daily abnormal returns are positive. Daily abnormal returns are highest on days 0 and +1 . Panel B shows that stock dividends elicit a significant positive stock market response at the .05 level or better for most windows tested $[(-1,0)(-2,+2)(-4,+4)$ $(-15,+15)]$. The $C A R$ s range from $0.789 \%$ for the two-day window to a substantial $4.603 \%$ for the thirty-one day window. The CAR's are somewhat higher using market-adjusted returns (.9\% and $5.27 \%$ ). Again, as in the case of cash dividends the eleven-day windows before $(-15,-5)$ and after $(+5,+15)$ the announcement are statistically insignificant. The presence of significant positive abnormal returns up to day +2 shows a somewhat delayed market reaction to the stock dividend announcement. The wider $(-15,+15)$ event-period window produces a statistically significant (at the $1 \%$ level) positive abnormal return of $4.6 \%$. In summary, the results in table 1 for stock dividends are more pronounced than the results on cash dividends and are supportive of hypothesis $H_{2}$. Moreover, given that the optimal trading price-range hypothesis is not applicable in this setting, the stock dividend results in table 2 are more supportive of the informationsignalling explanation (and, indirectly, of the exploitation by larger shareholders hypothesis).

The above results are noteworthy for several reasons: First, these positive wealth effects for both cash and stock dividends are in line with evidence documented by previous studies (e.g., Pettit [1972], and Grinblatt, Masulis, and Titman [1984]) on samples of U.S. firms, despite staging the tests in a substantially different context. Second, the emerging Cyprus stock market assimilates the new dividend information fairly quickly (within 2-4 days); the wealth effect after day +4 is negligible. The somewhat delayed wealth effect may be partly explained by the fact that our event dates reflect the time that firms privately communicated dividend payout information to the managing board of the stock exchange $(t=0)$, typically after trading hours. ${ }^{6}$ Investors could apparently first trade on that information on the following day $(t=+1)$. Alternatively, they may reflect the fact that, due to thin trading, some firms do not trade prior to day +2 . In a related vein, the announcement does not seem to be preceded by significant

6. Active trading in the Cyprus stock market currently takes place Monday through Friday between 10:30 a.m. and 12:00 noon. Since the dividend announcements are typically made during board meetings that take place in the afternoon (after trading hours), the impact of the announcement is actually incorporated into next day's price (w hich could, alternatively, have been interpreted as day-0 instead). 
TABLE 2. Descriptive Statistics on Selected Variables for Firms Announcing Dividend Policy Changes in the CSE

\begin{tabular}{lcccr}
\hline & $n$ & Mean & Median & $\begin{array}{r}\text { Positive/ } \\
\text { negative }\end{array}$ \\
\hline A. Cash Dividend Increases & & & & \\
Market-to-book ratio & 39 & 1.47 & 1.16 & \\
Free cash flow/ total assets & 39 & $6.25 \%$ & $6.48 \%$ & \\
One-year change in return on equity & 30 & $.89 \%$ & $.4 \%$ & $17 / 13$ \\
Two-year change in return on equity & 27 & $5.96 \%$ & $-.1 \%$ & $13 / 14$ \\
& & & & \\
B. Stock Dividends & & & & \\
Pre-bonus price & 39 & 3.72 & 2.46 & \\
Pre-bonus adjusted price & 39 & $1.67 * *$ & $.54^{* * *}$ & $28 / 11^{* * *}$ \\
One-year change in return on equity & 30 & $.62 \%$ & $1.1 \% \%^{* *}$ & $22 / 8^{* * *}$ \\
Two-year change in return on equity & 27 & $.99 \%$ & $4.1 \% 0^{* *}$ & $21 / 8^{* *}$ \\
\hline
\end{tabular}

Note: Descriptive statistics for variables proxying for free cash flow and signaling effects for dividend changes (panel A) and for liquidity and signaling effects for stock dividends (panel B). Market-to-book is equity capitalization plus total liabilities, all divided by total assets; free cash flow is net income plus depreciation; one- and two-year change in return on equity is the percentage change in accounting return on equity one and two years after the event; pre-bonus price is the share price two calendar months before the event announcement; pre-bonus adjusted price is the difference between the firm's share price and the corresponding average industry share price two months before the event announcement. Asterisks in the mean, median, and positive/negative columns indicate statistical significance using the $t$-test, Wilcoxon $Z$, and sign tests respectively; ${ }^{*}, * * * * *$ indicates significant at the $.1, .05$, and .01 level, respectively.

abnormal returns in the trading days before cash dividend announcements, signifying little information leakage. However, there may have been some information leakage in the case of stock dividends going back to day -4 . On the other hand, the apparent spread of $A R \mathrm{~s}$ during the several days around the announcement may also be partly due to the difficulty in pin-pointing the event date precisely in the context of the Cyprus market. The changes in cash dividends identified here may not always have been deliberate managerial decisions of particular significance. In some cases, an increase in cash dividends may have been the result of accumulation of previous dividend omissions that were aggregated over longer time periods. Such irregularities in the timing of cash dividend payments would clearly increase the noise and work against the statistical significance of our results. Even so, the significant positive $C A R$ s within two days surrounding the cash 
dividend announcements do support hypothesis $H_{1}$. The evidence on stock dividend (bonus) announcements is more significant in support of hypothesis $H_{2}$.

\section{Testing Between Competing Explanations for Dividend Policy}

To probe further into the reasons for the positive stock market reaction to cash and stock dividend announcements, we constructed proxies for the major competing explanations for cash dividends (signaling vs. free cash flow) and for stock dividends (signaling vs. liquidity). ${ }^{7,8}$ We then empirically link these proxies of competing theories to the stock market reaction to cash and stock dividends to see if differences in market reaction across constructs may help illuminate the validity of alternative dividend policy explanations.

First, to disentangle between alternative explanations for cash dividend increases we adopt empirical proxies of information-signaling and free cash flow effects. For this purpose, we utilized the annual reports of all firms that were listed in the Cyprus Stock Exchange during the sample period to create a data set of financial variables that would enable constructing these empirical proxies. To measure the amount of information contained in cash dividend increases we used the change in earnings following the dividend increase announcement. Specifically, we measure the accounting return on equity (ROE, or net income over the book value of equity) in the year of the event, and compare it to the return on equity one and two years after the event. The larger the percentage change in the return on equity, the stronger the positive signal about future operating cash flows that is conveyed through the dividend increase. The use of earnings changes as a measure of the information contained in corporate transactions such as dividend changes and share repurchases has been extensively used in prior research (e.g., Healy and Palepu [1988] and Dann, Masulis, and Mayers [1991]). If the signaling hypothesis explains cash dividend increases

\footnotetext{
7. We thank an anonymous referee for suggesting this set of tests.
}

8. Our data do not allow us to test for the validity of the tax explanation across firms. Nevertheless, the positive market reaction to cash dividend increases suggests that explanations other than taxes dominate the reasons for dividend increases in our sample. 
well, we would expect a stronger stock market reaction to dividend changes for stronger post-event ROE improvements.

To discern the free cash flow effects of cash dividend increases, we employ two empirical constructs: first, the higher the level of free cash flow (defined as net income plus depreciation), the greater the danger of fund misuse and the stronger the expected stock market reaction to cash dividend increases. The rationale is that higher cash flow levels are in greater danger to be wasted; such a danger can be reduced through a dividend payout. The use of the free cash flow variable as defined here is in line with Lang, Stulz, and Walkling (1991) who find that takeover bids are less beneficial to shareholders for firms with higher levels of free cash flow.

Second, the lower the level of the firm's growth opportunities the higher the market reaction to dividend increases. We proxy for growth opportunities using the market-to-book ratio, defined as share price times common shares outstanding, plus total liabilities, all divided by total assets at the start of the year. The market-to-book ratio is a reasonable proxy for Tobin's $q$ (see Perfect and Wiles [1994]) that is a theoretically appealing proxy for growth, while its computation is less demanding in terms of data collection and processing.

Turning to stock dividends, information signaling effects are measured using one- and two-year changes in accounting return on equity as defined earlier. Liquidity effects are measured using the share price two calendar months before the stock dividend announcement date. This approximation relies on prior research suggesting that managers may split their stock to reduce prices and improve marketability (Lakonishok and Lev [1987]). Thus, stocks with greater than optimal prices are, on average, less marketable. McNichols and Dravid (1990) further find that split factors are an increasing function of pre-split share prices.

We measure share prices two calendar months before the event to ensure that the event itself did not affect the pre-event share price. First, the unadjusted firm share price is used as a liquidity criterion for each firm. A second liquidity criterion subtracts the average share price of each firm's industry from the firm's share price two months before the stock dividend announcement. This second measure considers the possibility that liquidity considerations, and thus the need to employ a stock dividend for this purpose, may vary across industry groupings. The expectation is that the market reaction to announcements with a greater signaling effect would be more closely related to changes in 
earnings, while in announcements with a stronger liquidity effect the market reaction would be more closely related to share price levels, whether raw or industry-adjusted, signifying a greater liquidity benefit of stock dividends for firms with share prices above the optimal trading range.

Table 2 provides descriptive statistics for the variables of interest pertaining to cash dividends (panel A) and stock dividends (panel B). Focussing first on panel A, earnings changes after dividend increases are weak and insignificant, casting doubt on the signaling effect of cash dividends on future earnings. By contrast, both one- and two-year increases in earnings are positive and significant after the announcement of stock dividends, suggesting that stock dividend announcements do signal information about future earnings. Further, firms announcing a stock dividend tend to have a significantly higher share price than the average firm in their industry, consistent with a liquidity explanation for stock dividends. These differences are significant using the parametric $t$-test, as well as the non-parametric Wilcoxon and sign tests.

In table 3 we test for differences in cumulative abnormal returns $(-2,+2)$ based on differences in signaling, free cash flow, and liquidity proxies across firms. Specifically, we partition each of the samples in two, based on the median of each of the variables proxying for the competing explanations described earlier. The expectation is that 1) firms with a high post-event earnings change would experience more positive announcement-period returns according to the signaling hypothesis (cash and stock dividends); 2) low growth (low market-tobook) and high free-cash-flow firms would experience a stronger market reaction according to the free cash flow hypothesis (cash dividends), and 3) firms with a high pre-announcement share price, both raw and industry-adjusted, would experience a stronger market reaction according to a liquidity argument (stock dividends). The empirical results are generally uninformative on the validity of alternative dividend policy explanations. Specifically, none of the univariate differences between the five-day announcement-related returns is statistically significant at any conventional level under the parametric and non-parametric tests, suggesting that the empirical constructs employed here cannot help distinguish between the above alternative explanations for the stock market reaction.

In further tests, we employed two multivariate OLS regressions 
TABLE 3. Comparison of Firms Announcing Dividend Policy Changes in the CSE Based on Selected Variables

\begin{tabular}{lcccc}
\hline & & & & Wilcoxon \\
& $<$ median & $>$ median & $t$-statistic & $z$-statistic \\
\hline A. Cash Dividends $(n=41)$ & & & & \\
Market-to-book ratio & $1.21 \%$ & $2.76 \%$ & -.52 & -.24 \\
Free cash flow/ total assets & $2.51 \%$ & $1.26 \%$ & .9 & 1.29 \\
One-year change in return on equity & $1.77 \%$ & $3.52 \%$ & -.99 & -1.33 \\
Two-year change in return on equity & $2.19 \%$ & $3.27 \%$ & -.55 & -.01 \\
& & & & \\
B. Stock Dividends $(n=39)$ & & & & \\
Pre-announcement price & $4.51 \%$ & $1.74 \%$ & $2.12 * *$ & $1.65 *$ \\
Pre-announcement adjusted price & $3.6 \%$ & $2.65 \%$ & .69 & 1.22 \\
One-year change in return on equity & $.62 \%$ & $1.1 \%$ & -.85 & -.77 \\
Two-year change in return on equity & $3.88 \%$ & $1.8 \%$ & 1.41 & -1.11 \\
\hline
\end{tabular}

Note: Cumulative abnormal return $(C A R)$ comparisons for samples of cash dividend increases (panel A) and stock dividends (panel B) partitioned on the basis of free cash flow, signaling, and liquidity variables at the sample median. Cumulative abnormal return is riskadjusted from $t=-2$ to $t=+2$. Market-to-book is equity capitalization plus total liabilities, all divided by total assets; free cash flow is net income plus depreciation; one- and two-year change in return on equity is the percentage change in accounting return on equity one and two years after the event (changes in one- and two-year return on equity are based on 31 and 28 observations respectively in panel $\mathrm{A}$, and on 30 and 27 observations in panel $\mathrm{B}$ ); pre-bonus price is the share price two calendar months before the event announcement; pre-bonus adjusted price is the difference betw een the firm's share price and the corresponding average industry share price two months before the event announcement. ${ }^{*}, * *$ significant at the .1 and .05 levels, respectively.

(results not tabulated) to examine the relative explanatory power of the various proxies for our research hypotheses listed in panels $\mathrm{A}$ and $\mathrm{B}$ of table 3 in explaining the five-day $(-2,+2)$ announcement period return. Specifically, we regressed cash dividend return on free cash flow, market-to-book, and one-year earnings change, and the stock dividend return on the pre-dividend share price, and one-year earnings change. Neither model $F$-statistic nor the individual variable coefficients are significant at any conventional level in either model, consistent with earlier univariate results. The models' $R^{2}$ values are negligible. Because of the limited sample sizes that substantially reduce test power, we consider these OLS results less reliable. In any case, we do not discern systematic differences in announcement-related returns under either univariate or multivariate statistical comparisons. 
In the backdrop of the positive market reaction to these announcements and the corroborating evidence from table 1 for stock dividends, these non-results may be qualified by the small sample sizes and noisy empirical constructs. Alternatively, uninformed investors in such a small emerging market may be unable to discern the different valuation implications of dividend policy decisions across firms with different types of information, agency and liquidity characteristics.

\section{Conclusion}

In general, corporate payout policy in emerging markets should be interpreted in the backdrop of different market microstructures, tax regimes and control environments. In many emerging markets, the issue of corporate credibility is one of the most significant challenges faced by public firms in raising capital. The problem springs, in part, from the investing public's unfamiliarity with the market mechanisms, the lack of transparency and, in some cases, with a culturally-based suspicion against big businesses, managerial intentions and side-activities. The problem is intensified by the general lack of credible media for the dissemination of financial information, which in developed countries is provided by a specialized part of the press and the electronic media.

Examined in this light, one interpretation of the results is that the positive impact of dividend increases may reflect apparently effective attempts by Cyprus-listed firms to bridge the information asymmetry gap with investors via their dividend payout policy. The understanding of such efforts may be enhanced through an examination of the signalling value of alternative financial policy decisions, such as the corporate issue of equity and debt. An alternative interpretation of the positive impact of dividend increases may be that they serve to reduce potential exploitation of smaller shareholders by larger ones, with different policy implications regarding the need to enhance transparency (both at the corporate and market levels) and public confidence. Similarly, liquidity explanations of stock dividends cannot presently be ruled out. This study should best be seen as an attempt toward understanding the importance of corporate financial policies in emerging markets. 


\section{References}

Aharony, J., and Swary I. 1980. Quarterly dividend and earnings announcements and stockholders' returns: An empirical analysis. Journal of Finance 35: 1-12.

Angel, J. 1998. Tick size, share prices, and stock splits. Journal of Finance 52: 655-681.

Angel, J.; Brooks, R.; and Mathew, P. 1997. When-issued shares, small traders, and the variance of returns around stock splits. Working paper, Georgetown University (October).

Asquith, P.; Healy, P; and Palepu, K. 1989. Earnings and stock splits. The Accounting Review 64: 387-403.

Asquith, P., and Mullins, D. 1983. The impact of initiating dividend payments on shareholders' wealth. Journal of Business 56: 77-96.

Bernartzi, S.; Michaely, R.; and Thaler, R. 1997. Do changes in dividends signal the future or the past? Journal of Finance 52: 1007-1030.

Bernheim, D., and Wantz, A. 1994. A tax-based test of the dividend signaling hypothesis. W orking paper, Stan ford University.

Bhattacharya, S. 1979. Imperfect information, dividend policy, and the 'bird in the hand' fallacy. Bell Journal of Economics 10: 259-270.

Boehmer, E.; Musumeci, J.; and Poulsen, A. 1991. Event study methodology under conditions of event-induced uncertainty. Journal of Financial Economics 30: 253-272.

Copeland, T. 1979. Liquidity changes following stock splits. Journal of Finance, 34: 115-141.

Dann, L.; Masulis, R.; and Mayers, D. 1991. Repurchase tender offers and earnings information. Journal of Accounting and Economics 15: 217-251.

DeAngelo H., and DeAngelo, L. 2000. Controlling stockholders and the disciplinary role of corporate payout policy: A study of the Times Mirror Company. Journal of Financial Economics 56: 153-207.

DeAngelo H.; DeAngelo L.; and Skinner, D. 1992. Dividends and losses. Journal of Finance 47: 1837-1863.

Denis, D.; Denis, D.; and Sarin, A. 1994. The information content of dividend changes: Cash flow signalling, overinvestment, and dividend clienteles. Journal of Financial and Quantitative Analysis 29: 557-587.

Dennis, D., and McConnell, J. 1986. Corporate mergers and security returns. Journal of Financial Economics 16: 143-187.

Dimson, E. 1983. The stability of U.K. risk measures and the problem of thin trading. Journal of Finance 38: 753-783.

Fama, R.; Fisher, L.; Jensen, M.; and Roll R. 1969. The adjustment of stock prices to new information. International Economic Review 10: 1-21.

Grinblatt, M.; Masulis, R.; and Titman, S. 1984. The valuation effects of stock 
splits and stock dividends. Journal of Financial Economics 13: 461-490.

Howe, K.; He, J.; and Kao, W. 1992. One-time cash flow announcements and free cash flow theory: Share repurchases and special dividends. Journal of Finance 47: 1963-1975.

Healy, P., and Palepu, K. 1988. Earnings information conveyed by dividend initiations and omissions. Journal of Financial Economics 21: 149-175.

Holderness, C., and Sheehan, D. 1988. The role of majority shareholders in publically held corporations: An exploratory analysis. Journal of Financial Economics 20: 317-346.

Jensen, M. 1986. Agency costs of free cash flow, corporate finance, and takeovers. American Economic Review 76: 323-329.

Jensen, G., and Johnson, J. 1995. The dynamics of dividend reductions. Financial Management 24: 31-51.

Kryzanowski, L., and Zhang, H. 1996. Trading patterns of small and large traders around stock ex-split dates. Journal of Financial Research 19: 75 90.

Lakonishok, J., and Lev, B. 1987. Stock splits and stock dividends: Why, who, and when. Journal of Finance 42: 913-932.

La Porta, R.; Lopez-De-Silanes F.; Shleifer, A.; and Vishny, R. 2000. Agency problems and dividend policies around the world. Journal of Finance 55: $1-33$.

Lang, L., and Litzenberger, R. 1989. Dividend announcements: Cash flow signalling vs. free cash flow hypothesis? Journal of Financial Economics 24: 181-191.

Lang, L.; Stulz, R.; and Walkling, R. 1991. A test of the free cash flow hypothesis: The case of bidder returns. Journal of Financial Economics 29: 315-335.

McNichols, M., and Dravid, A. 1990. Stock dividends, stock splits, and signalling. Journal of Finance 45: 857-879.

Miller, M., and Modigliani, F. 1961. Dividend policy, growth, and the valuation of shares. Journal of Business 4: 411-433.

Miller, M.H., and Rock, K. 1985. Dividend policy under asymmetric information. Journal of Finance 40: 1031-1051.

Nohel, T., and Tarhan, V. 1998. Share repurchases and firm performance: New evidence on the agency costs of free cash flow. Journal of Financial Economics 49: 187-222.

Ofer, A., and Siegel, D. 1987. Tests of rational signalling models using expectations data: An application to dividend signalling. Journal of Finance 42: 889-911.

Perfect, S., and Wiles, K. 1994. Alternative constructions of Tobin's q: An empirical comparison. Journal of Empirical Finance 1: 313-341.

Pettit, R. 1972. Dividend announcements, security performance, and capital 
market efficiency. Journal of Finance 27: 993-1008.

Scholes, M., and Williams, J. 1977. Estimating beta from non-synchronous data. Journal of Financial Economics 5: 309-327.

Schultz, P. 2000. Stock splits, tick size, and sponsorship. Journal of Finance 55: 429-450.

Vafeas, N. 1997. Determinants of the choice between alternative share repurchase methods. Journal of Accounting, Auditing, and Finance 12:101124.

Yoon, P., and Starks L. 1995. Signalling, investment opportunities, and dividend announcements. Review of Financial Studies 8: 995-1018. 